\title{
Application of Different Image Processing Techniques on Aster and ETM+ Images for Exploration of Hydrothermal Alteration Associated with Copper Mineralizations Mapping Kehdolan Area (Eastern Azarbaijan Province-Iran)
}

\author{
Golchin Hajibapir ${ }^{1}$, Mohammad Lotfi ${ }^{2}$, Afshar Zia Zarifi ${ }^{3}$, Nima Nezafati ${ }^{1}$ \\ ${ }^{1}$ Department of Geology, Islamic Azad University, Science and Research Branch, Tehran, Iran \\ ${ }^{2}$ Department of Geology, Islamic Azad University, North Tehran Branch, Tehran, Iran \\ ${ }^{3}$ Mining Engineering Department, Islamic Azad University, Lahijan Branch, Lahijan, Iran \\ Email: g.hajibapiir@gmail.com
}

Received 23 September 2014; revised 20 October 2014; accepted 13 November 2014

Copyright (C) 2014 by authors and Scientific Research Publishing Inc.

This work is licensed under the Creative Commons Attribution International License (CC BY). http://creativecommons.org/licenses/by/4.0/

(c) (i) Open Access

\section{Abstract}

The Kehdolan area is located at 20 kilometers to the south-east of Dozdozan Town (Eastern Azarbaijan Province). According to structural geology, volconic rocks are situated in Alborz-Azarbyjan zone, and faults are observed in the same direction to this system with SE-NW trend. The results show that kaolinite alteration trend with Argilic and propylitic veins is the same direction with SW-NE faults in this area. Therefore, these faults with these trends can be considered as the mineralization control for determination of the alterations. Different image processing techniques, such as false color composite (FCC), band ratios, color ratio composite (CRC), principal component analysis (PCA), Crosta technique, supervised spectral angle mapping (SAM), are used for identification of the alteration zones associated with copper mineralization. In this project ASTER data are process and spectral analysis to fit for recognizing intensity and kind of argillic, propylitic, philic, and ETM+ data which are process and to fit for iron oxide and relation to metal mineralization of the area. For recognizing different alterations of the study area, some chemical and mineralogical analysis data from the samples showed that ASTER data and ETM+ data were capable of hydrothermal alteration mapping with copper mineralization. Copper mineralization in the region is in agreement with argillic alteration. SW-NE trending faults controlled the minerali- 


\section{zation process.}

\section{Keywords}

Kehdolan Area, False Color Composite, Band Ratios, Color Ratio Composite, Principal Component Analysis, Crosta Technique, Supervised Spectral Angle Mapping, ASTER Data, ETM+ Data, Alteration

\section{Introduction}

ASTER satellite data processing for mineralization mapping was used to detect alteration and detect mineral exploration targets [1] [2]. ASTER is the Advanced Spaceborne Thermal Emission and Reflection Radiometer, a multi-spectral sensor onboard one of NASA's Earth Observing System satellites, Terra, which was launched in 1999. ASTER sensors measure reflected and emitted electromagnetic radiation from earth's surface and atmosphere in 14 channels (or bands). There are three groups of channels: three recording visible and near infrared radiation (VNIR) at a spatial resolution of $15 \mathrm{~m}$; six recording portions of shortwave infrared radiation (SWIR) at a spatial resolution of $30 \mathrm{~m}$; and five recording thermal infrared radiation (TIR) at a resolution of $90 \mathrm{~m}$. The higher spectral resolution of ASTER (compared to Landsat, for example-Figure 1) especially in the shortwave infrared region of the electromagnetic spectrum makes it possible to identify minerals and mineral groups such as clays, carbonates, silica, iron-oxides and other silicates. An additional backward-looking band in the VNIR makes it possible to construct digital elevation models from bands 3 and 3b. ASTER swath width is $60 \mathrm{~km}$ (each scene is $60 \times 60 \mathrm{~km}$ ) which makes it useful for regional mapping [3].

There are a few things to note when using ASTER imagery for regional mineralogical mapping. Firstly, cloud cover, vegetation and atmospheric effects can severely mask or alter surface signals in this project ASTER, ETM+ data to correct with log residuals calibration method at ENVI 5/1 software [4] [5]. Secondly, bands and band ratios do not indicate the occurrence of a mineral with absolute certainty or with any idea of quantity, so this step is essential on ground truth and set appropriate thresholds. Thirdly, every terrain is different, so ratios which work in some areas for a particular mineral or assemblage may not show the same thing elsewhere. As a result of these factors, it is important not to look at ASTER images in isolation from other data. If possible, datasets such as geology and structural maps, geochemistry, PIMA analyses (ground truthing), radiometrics, and

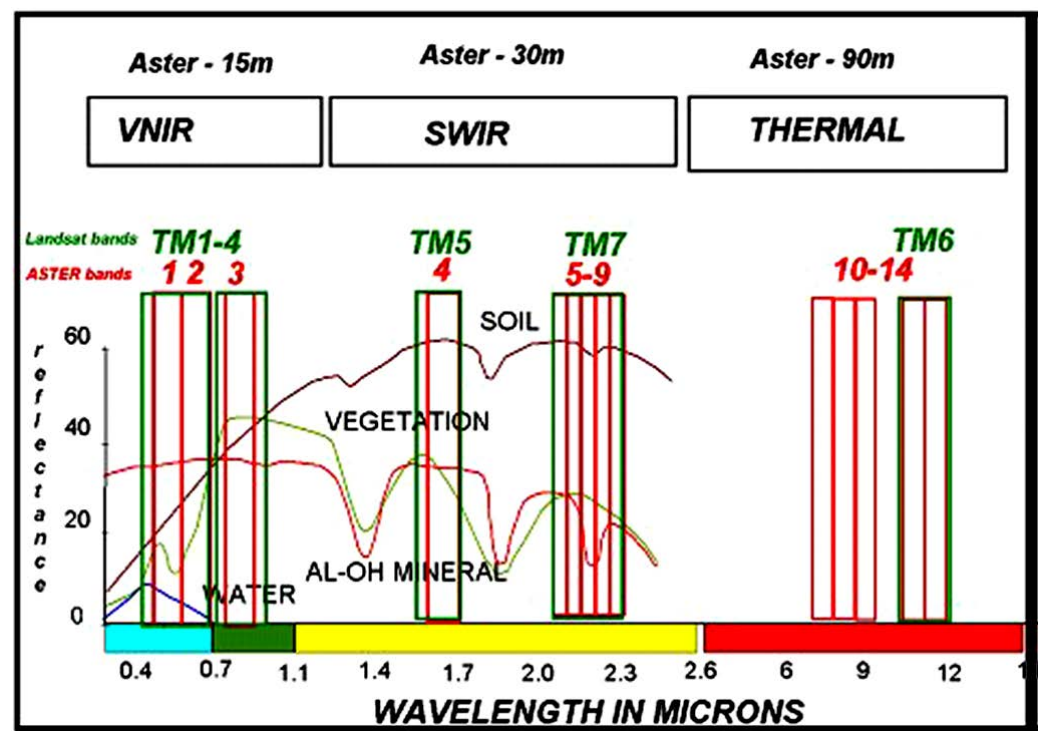

Figure 1. Distribution of ASTER and Landsat channels with respect to the electromagnetic spectrum. 
any other available data should be used in conjunction with ASTER for best results [6] [7]. Several methods have been conducted for recognizing different alterations with ASTER data. Different image processing techniques such as false color composite, band ratios, color ratio composite, principal component analysis, Crosta technique, supervised spectral angle mapping, and neural network classification are used for identification of the alteration zones associated with copper mineralization. The principal component analysis (PCA), Crosta technique, and supervised spectral angle mapping (SAM) method seem to be equally applicable to all cases for detecting alteration zone and minerals. In this study, concentration-area, Crosta technique, and supervised spectral angle mapping method were used [6] [8].

\section{Concentration-Area}

In recent years, application of remote sensing in mineral exploration had been developed and becoming an important tool. Most important capability of satellites in mining exploration is recognizing altered area. Because of close spatial relationship between mineral deposits and alteration, mineral mapping based of satellite data accelerate the exploration and reduce the cost [8].

The principal component analysis (PCA), Crosta technique to know by person in 1901, in 1933 Helting suggested to calculate method [9] [10]. The target enter variable $\mathrm{p}$ of $\mathrm{X}_{1} \ldots \mathrm{X}_{\mathrm{p}}$, and know compound of $\mathrm{p}$ for component $Z_{1} \ldots Z_{p}$, do not correlation [9] [11]-[15]. Classification supervised spectral angle mapping (SAM) need to ROI educationa file. SAM method by reason angel pixel to fabricate in $\mathrm{N}$ dimention with coordinates axise [16] [17].

\section{Geological Setting of the Case Studies}

The Studies area is located at 20 kilometers south-east of Dozdozan Town (Eastern Azarbaijan Province). According to structural geology, volconic rocks are situated in Alborz-Azarbyjan zone, and faults observe in same direction to this system with SE-NW trend that these are cut off with new faults with SW-NE trend. The results show that kaolinite alteration trend with Argilic and propylitic veins are same direction with SW-NE faults in this area.

Therefore, these faults with these trends can be considered as the mineralization control for determination of the alterations. Oldest rock types in the area are Eocene Andesit-Basalt.

There are Eocene-Oligocene sedimentary units including: marl, Nummolitic sandy limestone, Tuff breccia.

There are Oligocene Syenit dyke as in central parts of the study. Geology map digiting for Arc Gis 10 soft waer (Figure 2). The result ETM+ image processing techniques by False color composite (FCC (band 7, 4, 2)) show: pink color (volcanic rock), red brown color (iron oxide-manganese oxide), gray blue, white color (clay minerals) was capable with Geological unit and Fult at geological map [18] [19]. FCC (band 7, 4, 2) image processing for ENVI 5/1 software (Figure 3).

\section{The Principal Component Analysis (PCA)}

ASTER, ETM+ image processing techniques by PCA for band (1 ... 9 ASTE), band (1 ... 7 ETM+) for exist alteration for ENVI 5/1 software was calculated. Light point exist ASTER PC2 Image to show Altration area with band math 4/9 (Figure 4). Light point exist ASTER PC7 reverse image to show vegetation cover with band math 3/2 (Figure 5). Light point exist ETM+ PC5 image show Argilic Altration area with band math 5/7 (Figure 6). Light point exist ETM+ PC7 reverse image show iron oxide with band math 3/1 (Figure 7). Special vector matrise PCA ASTER, ETM+ (Table 1, Table 2) [20]-[23].

\section{Crosta Technique for Special Mineral Evidend}

Crosta technique for muscovite mineral at band (1, 6, 7, 9 ASTER image) was calculated (Table 3). Moscovite mineral have high reflection at band 7 and high absorption at band 6 [24]-[28].

High light exist at PC3 reverse image capable muscovite mineal, target of philic altration (Figure 8).

Crosta technique for kaolinite mineral at band (5, 6, 7 ASTER image) was calculated (Table 4). Kaolinite mineral have high reflection at band 7, 5 and high absorption at band 6 [26] [29] [30].

High light exist at PC1 image capable kaolinite mineal, target of Argilic altration (Figure 9). 


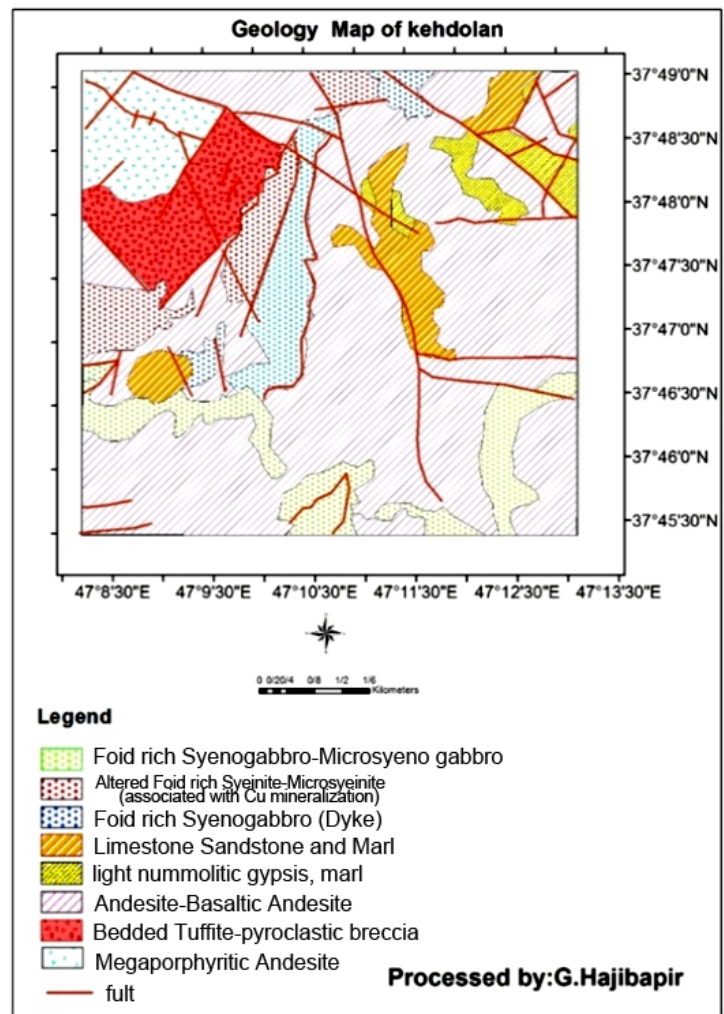

Figure 2. Kehdolan geological map.

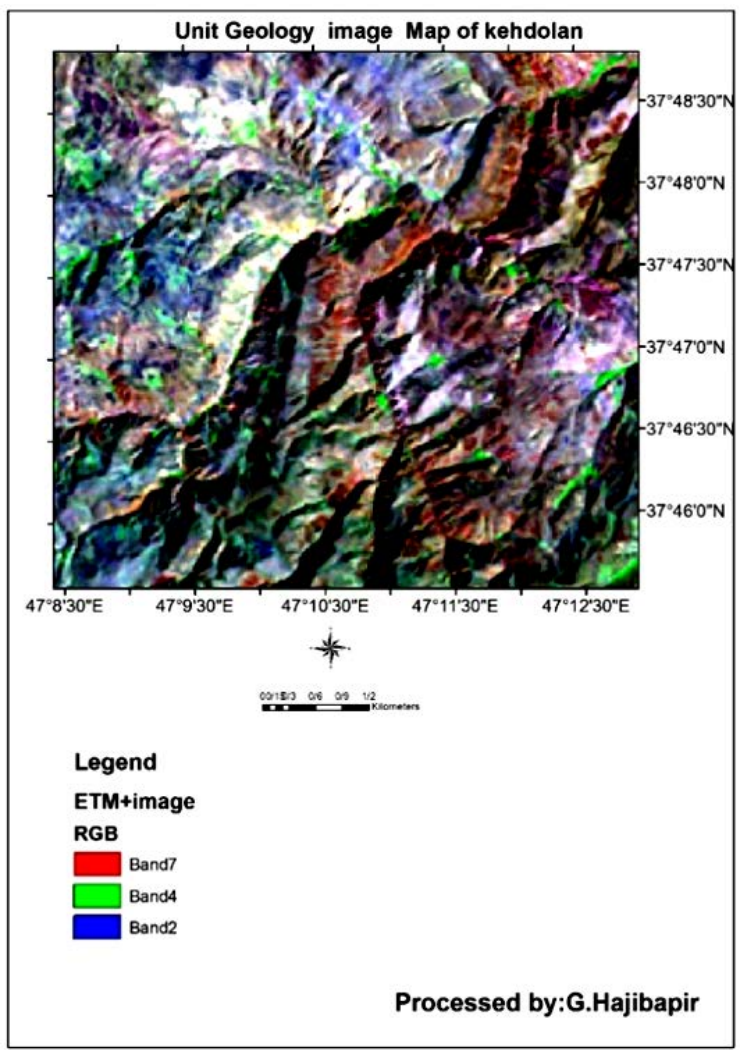

Figure 3. FCC (band 7, 4, 2) image (evident geological unit). 


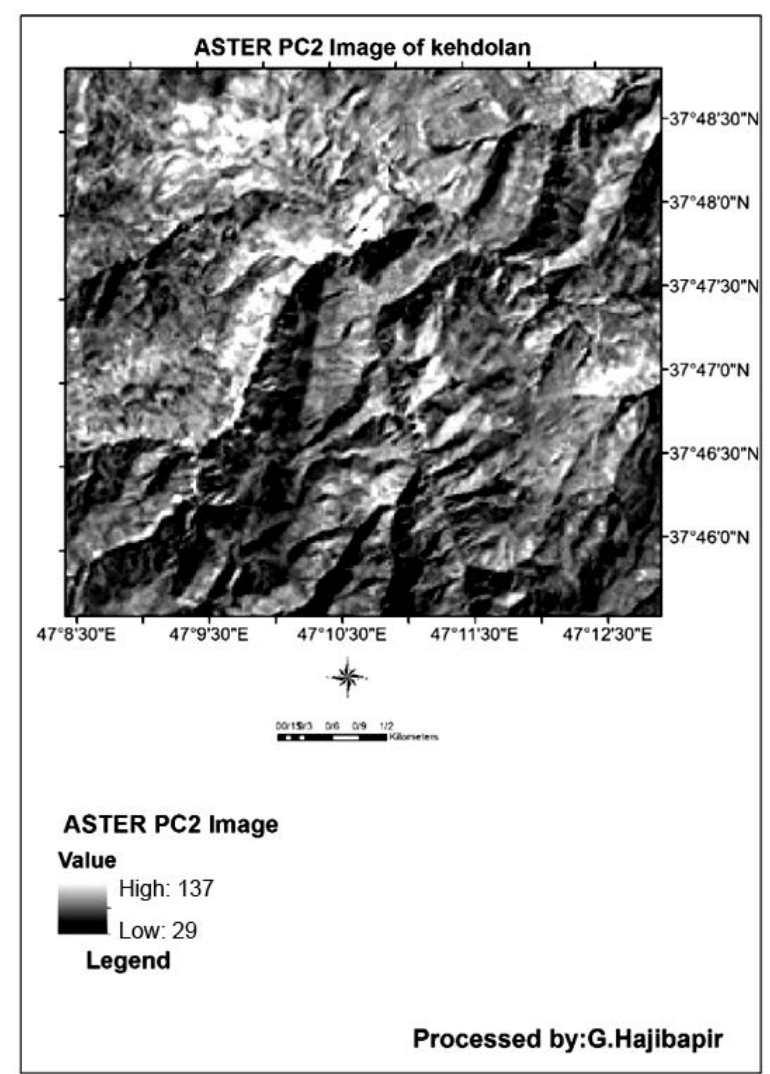

Figure 4. Altration image.

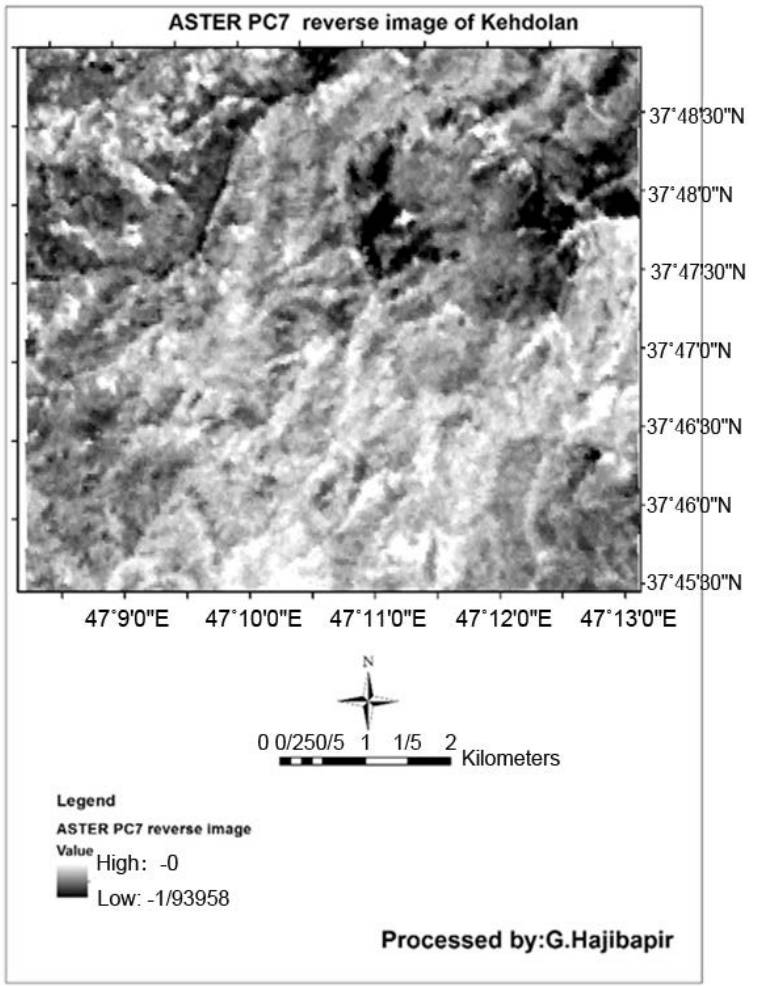

Figure 5. Vegetation cover image. 


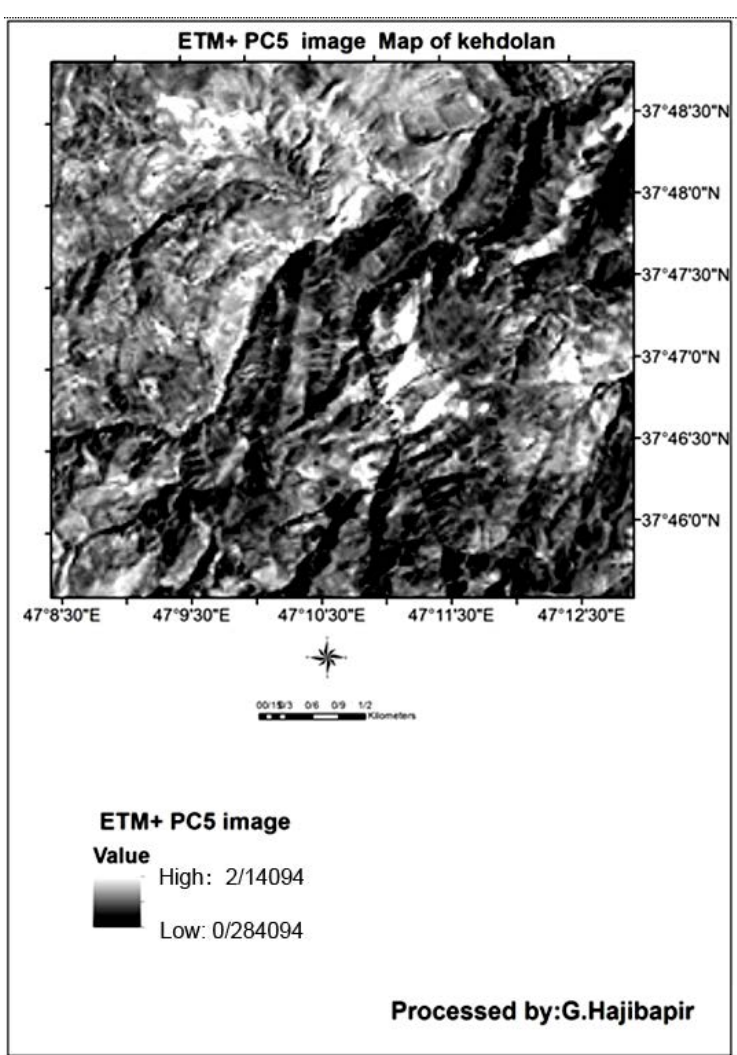

Figure 6. Argilic altration image.

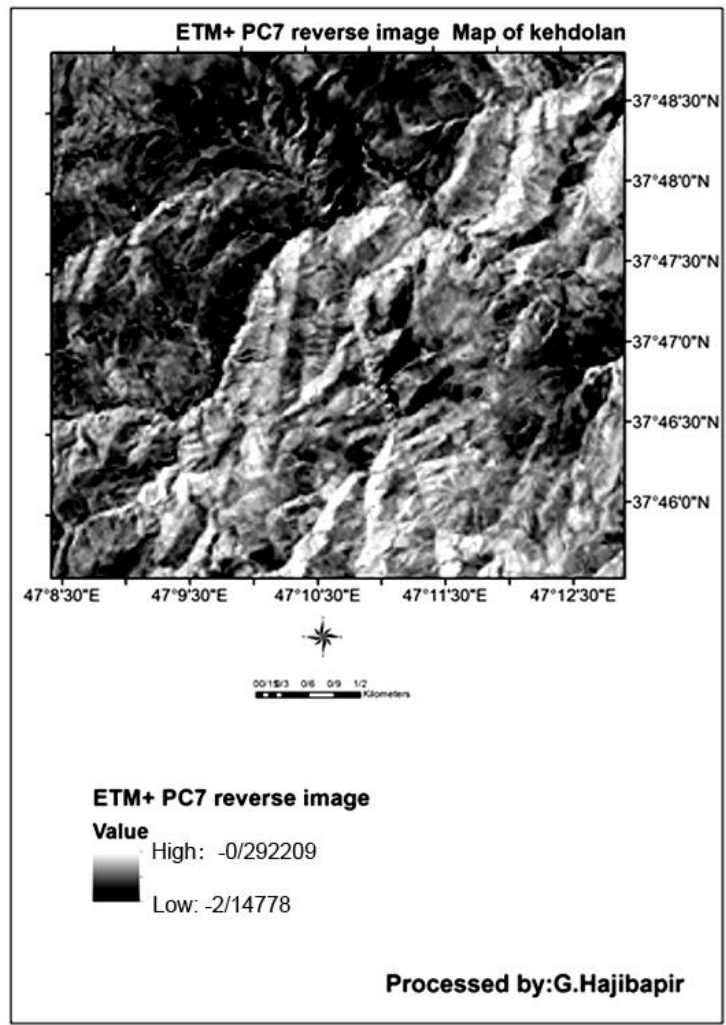

Figure 7. Iron oxide image. 
Table 1. Special vector matrise PCA ETM+.

\begin{tabular}{cccccccc}
\hline & PC1 & PC2 & PC3 & PC4 & PC5 & PC6 & PC7 \\
\hline Band 1 & 0.399579 & 0.200875 & 0.493121 & 0.154518 & 0.488643 & 0.383517 & 0.383517 \\
Band 2 & 0.371749 & 0.438192 & -0.225847 & 0.587692 & -0.518341 & 0.048603 & 0.048603 \\
Band 3 & 0.237005 & 0.144606 & 0.495941 & 0.119490 & 0.104559 & -0.570855 & -0.570855 \\
Band 4 & 0.386382 & 0.500228 & -0.176357 & -0.750152 & -0.077181 & -0.018619 & -0.018619 \\
Band 5 & 0.000011 & 0.224469 & -0.612875 & 0.230287 & 0.689673 & -0.150528 & -0.150528 \\
Band 6 & -0.704753 & 0.667916 & 0.230542 & 0.026524 & -0.003510 & 0.040896 & 0.040896 \\
Band 7 & 0.000000 & 0.000000 & 0.000000 & 0.000000 & -0.000000 & -0.707107 & 0.707107
\end{tabular}

Table 2. Special vector matrise PCA ASTER.

\begin{tabular}{cccccccccc}
\hline & PC1 & PC2 & PC3 & PC4 & PC5 & PC6 & PC7 & PC8 & PC9 \\
\hline Band 1 & -0.984200 & -0.062615 & -0.063883 & -0.062453 & -0.062168 & -0.062412 & -0.062469 & -0.062665 & -0.062121 \\
Band 2 & -0.176090 & 0.427395 & 0.372248 & 0.367633 & 0.328495 & 0.329038 & 0.318682 & 0.305686 & 0.318474 \\
Band 3 & 0.008835 & 0.163848 & 0.858800 & -0.213433 & -0.168468 & -0.195883 & -0.202049 & -0.225476 & -0.177678 \\
Band 4 & 0.015454 & 0.859775 & -0.337544 & 0.066219 & -0.128494 & -0.143264 & -0.159675 & -0.223912 & -0.171930 \\
Band 5 & -0.004572 & 0.202582 & -0.073348 & -0.863289 & 0.127182 & 0.092710 & 0.006612 & 0.208492 & 0.374177 \\
Band 6 & -0.002133 & 0.077985 & 0.013448 & -0.128062 & -0.249657 & -0.084614 & 0.342275 & 0.655681 & -0.600646 \\
Band 7 & 0.000521 & -0.014035 & -0.015863 & -0.185674 & 0.693815 & 0.259831 & 0.117439 & -0.306588 & -0.555335 \\
Band 8 & 0.000742 & -0.000442 & 0.007915 & 0.015152 & -0.230679 & 0.752930 & -0.571919 & 0.168557 & -0.155203 \\
Band 9 & 0.000018 & 0.005981 & -0.001192 & -0.120972 & -0.479831 & 0.422817 & 0.608391 & -0.453716 & 0.017819 \\
\hline
\end{tabular}

Table 3. Special vector matrise band (1, 6, 7, 9 ASTER image).

\begin{tabular}{ccccc}
\hline & PC1 & PC2 & PC3 & 0.063059 \\
Band 1 & 0.994043 & 0.063001 & 0.062708 \\
Band 2 & -0.108979 & 0.583396 & 0.568724 & 0.799496 \\
Band 3 & -0.000019 & -0.216552 & -0.570891 & 0.588778 \\
Band 4 & -0.001215 & -0.780247 & 0.211078 \\
\hline
\end{tabular}

Crosta technique for carbonates (Cholorit, Epidotes, Calcite) mineral at band (1, 7, 8, 9 ASTER image) was calculated (Table 5). This mineral have high reflection at band 7, 9 and high absorption at band 8 [26] [29] [31]. High light exist at PC4 reverse image capable Carbonates mineal, target of prophilitic altration (Figure 10).

\section{Supervised Spectral Angle Mapping (SAM)}

The result ASTER, image processing techniques by supervised spectral angle mapping (SAM) method with 0/1 angle do spectral on CRC ((B5 + B7)/B6, (B4 + B6)/B5, (B7 + B9)/B8) ASTER image (Figure 11) [32]-[35]. The result target to (Philic, Argilic, Prophilic) Altration exist at study area. The result target four important altration area. Therefore NW area is case study [36]-[43]. SAM image to show excess Philic at NW, E trend and capable Foid rich Syeinogabro unit geology (Figure 12). SAM image to show excess Argilic at central by SW-NE trend and capable major fault area, Altered Syeinit unit geology (Figure 13). SAM image to show excess Charbonates at NW, SW, E, E trend and capable Andesit-basalt, tuff with limeston study area unit geology (Figure 14). The CRC (B7/B5, B2/B1, B3/B1) image (ETM+) to show red color excess iron oxid (Magnetit) (Figure 15). 


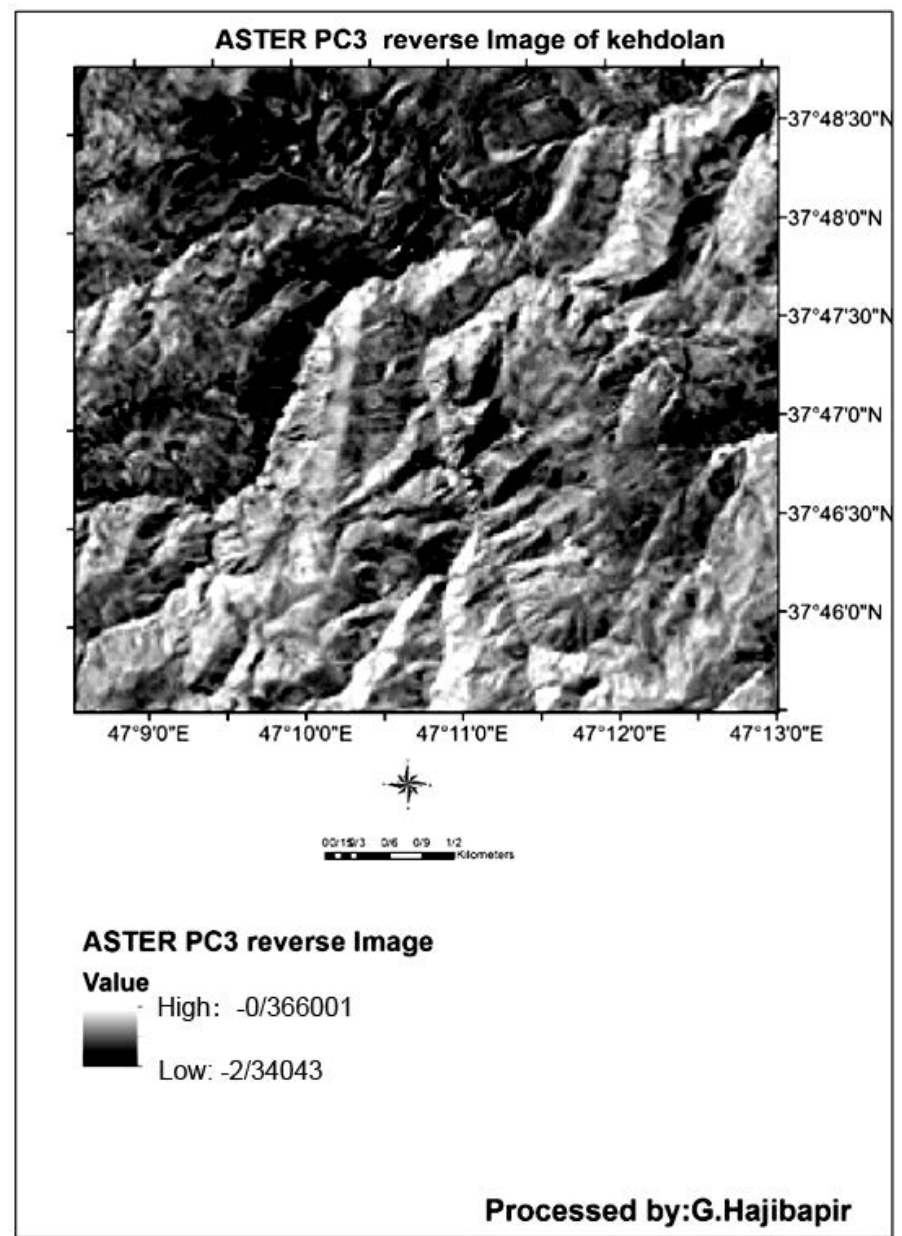

Figure 8. Moscovite mineral image.

Table 4. Special vector matrise band (5, 6, 7 ASTER image).

\begin{tabular}{cccc}
\hline & PC1 & PC2 & PC3 \\
\hline Band 1 & -0.568074 & -0.578693 & -0.585154 \\
Band 2 & -0.437825 & -0.389543 & 0.810287 \\
Band 3 & -0.696851 & 0.716498 & -0.032077 \\
\hline
\end{tabular}

\section{Control with Geological Particulars, XRD, ICP, Doubly-Polished Thin Section, Heavy Mineral}

Altration the study area controlled by ICP sample and result obtained exist high copper and Fe element (Table 6) three distribution for copper exist the probable anomaly and possible anomaly and field, distribution by geostatisic method used. XRD sample result show (Table 7) that result showed clay mineral and Iron oxide. The coordinates of sampling points in Kehdolan area show at Figure 16. Heavy mineral sample result showed (Table 8) that native copper and iron oxide minerals.

Doubly-polished thin section result show at Figure 17, and result copper-iron mineralization. At all doublypolished thin section exist minerals: covellite and chalcosite (B, A-image), altered magnetite (C-image), pyrite with Ti exsolution (E-image), bornite (D-image), altered magnetite with ilmenite exsolution (F-image), hematite and chalcosite (G-image), covellite and pyrite (H-image). 


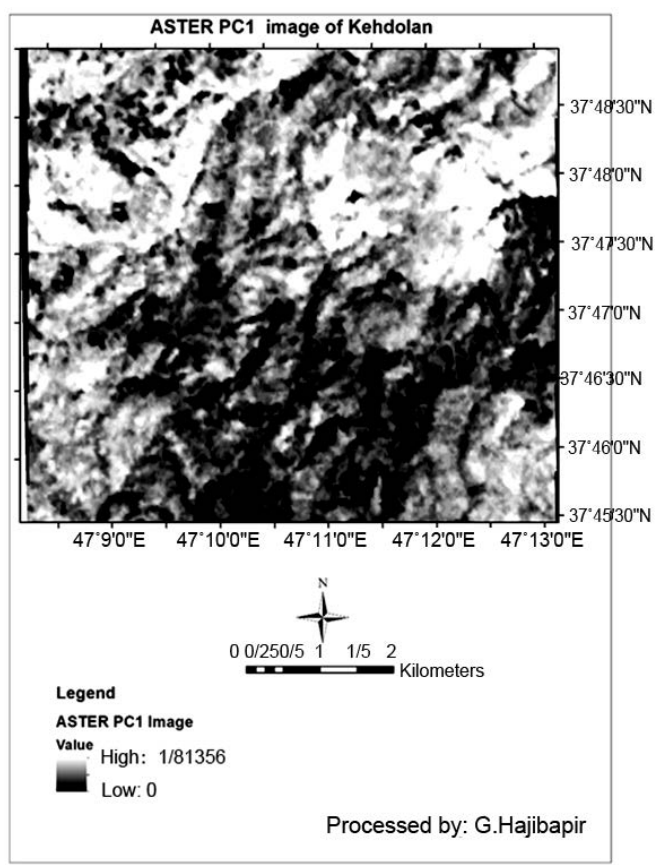

Figure 9. Kaolinit mineral image.

Table 5. Special vector matrise band (1, 7, 8, 9 ASTER image).

\begin{tabular}{ccccc}
\hline & PC1 & PC2 & PC3 & PC4 \\
\hline Band 1 & 0.994027 & 0.063058 & 0.063258 & 0.062707 \\
Band 2 & -0.109131 & 0.575296 & 0.571368 & 0.575033 \\
Band 3 & -0.000545 & 0.362833 & 0.453723 & -0.813933 \\
Band 4 & -0.000410 & -0.730350 & 0.680935 & 0.054011 \\
\hline
\end{tabular}

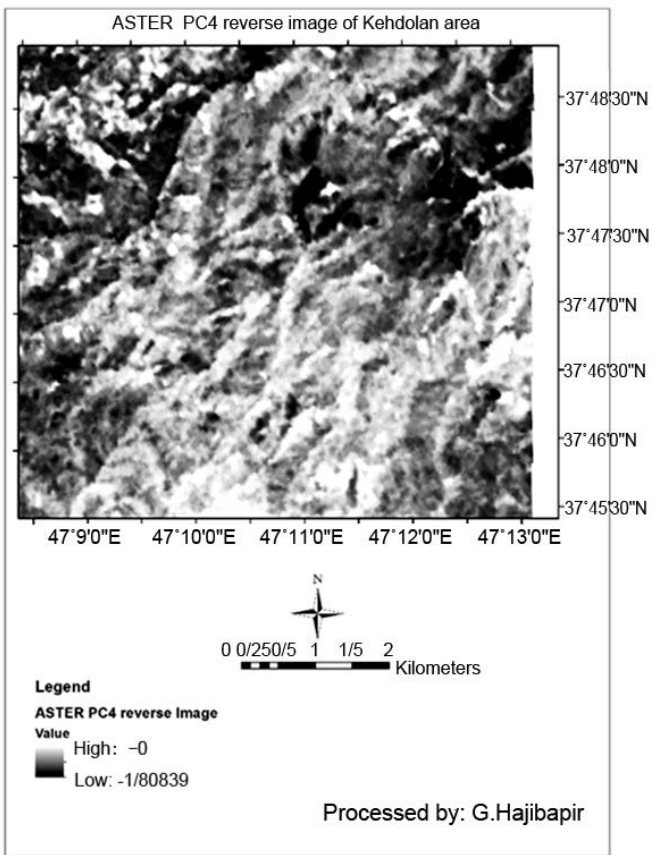

Figure 10. Charbonates mineral image. 


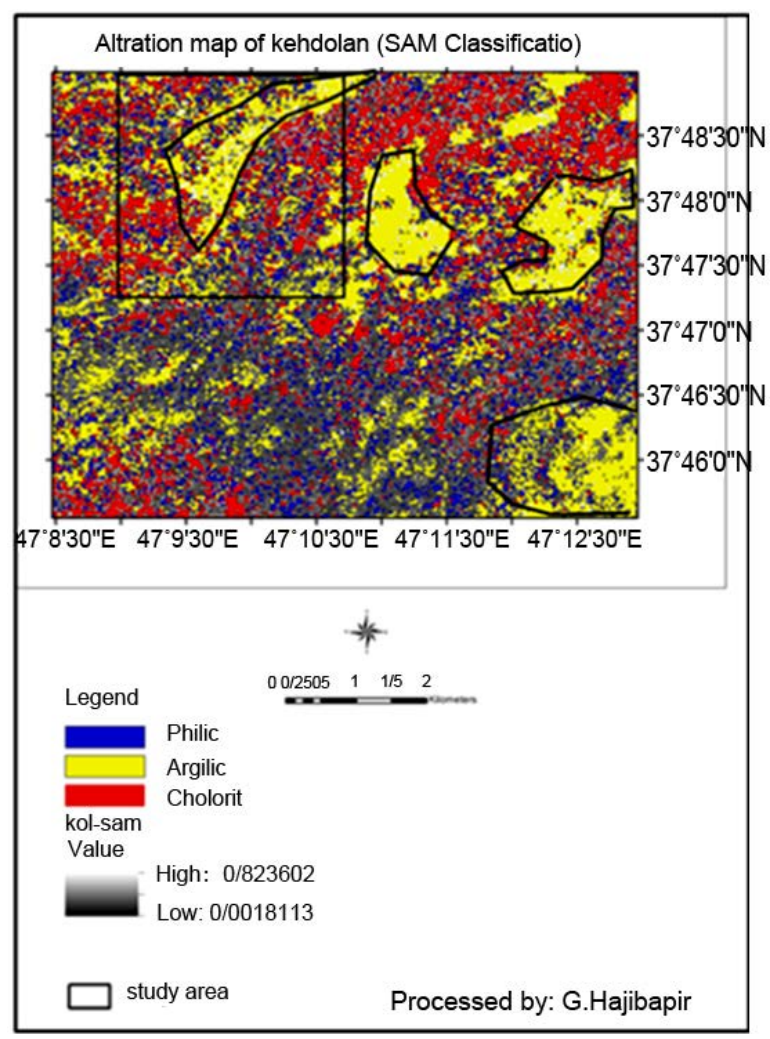

Figure 11. Final map (SAM).

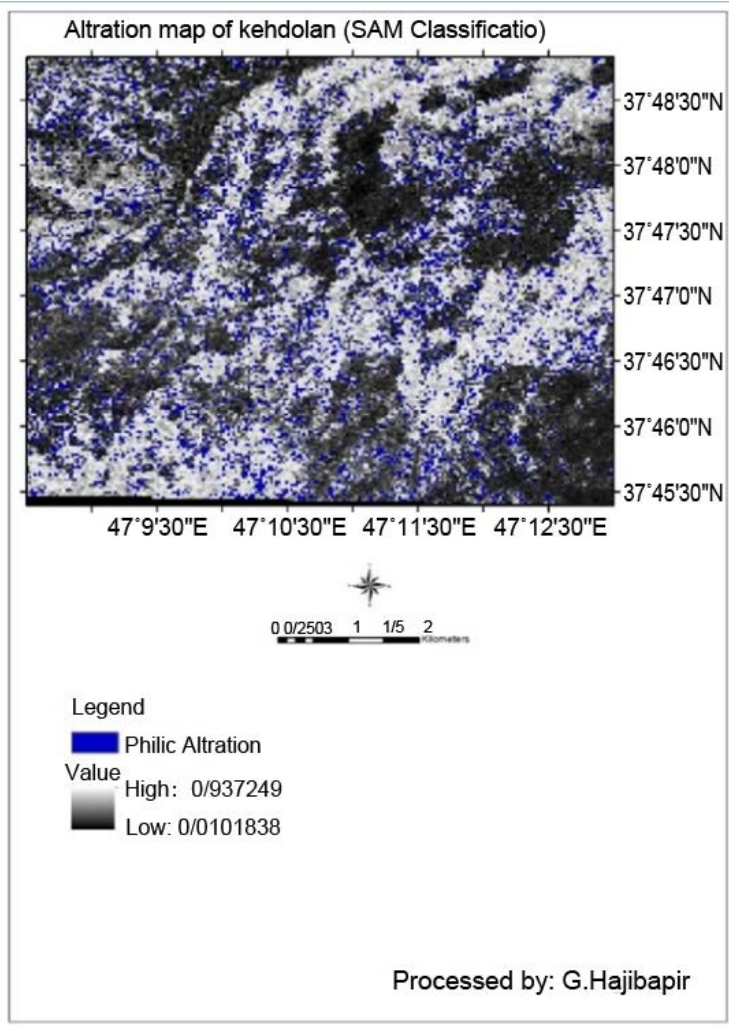

Figure 12. Philic map (SAM). 


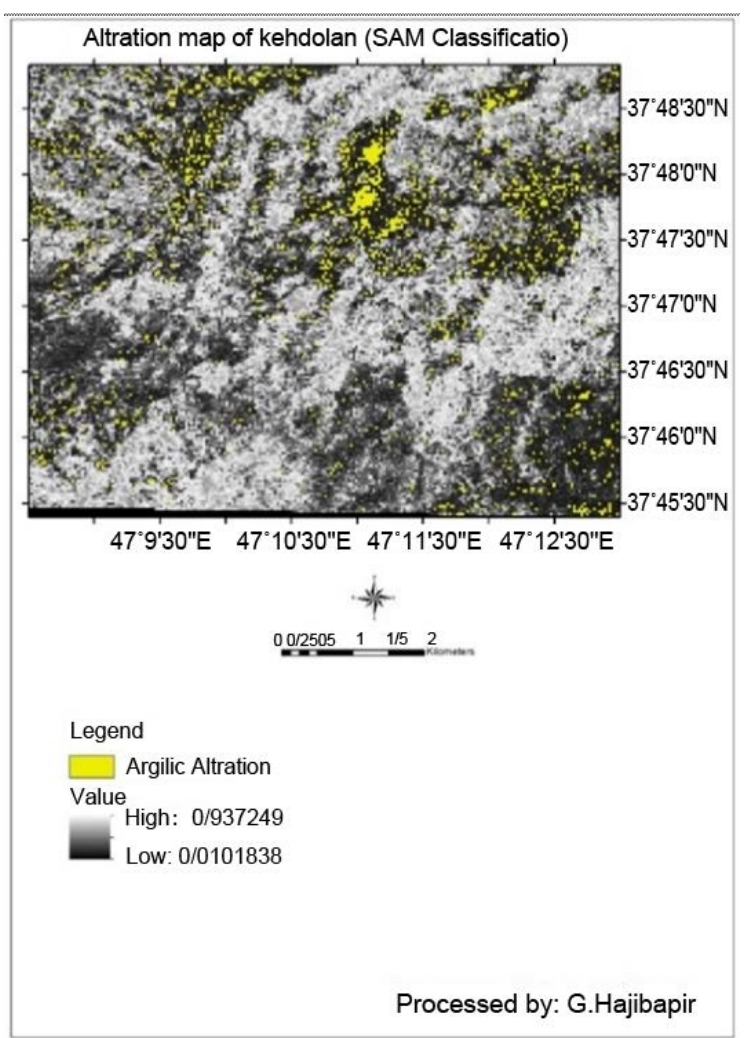

Figure 13. Argilic map (SAM).

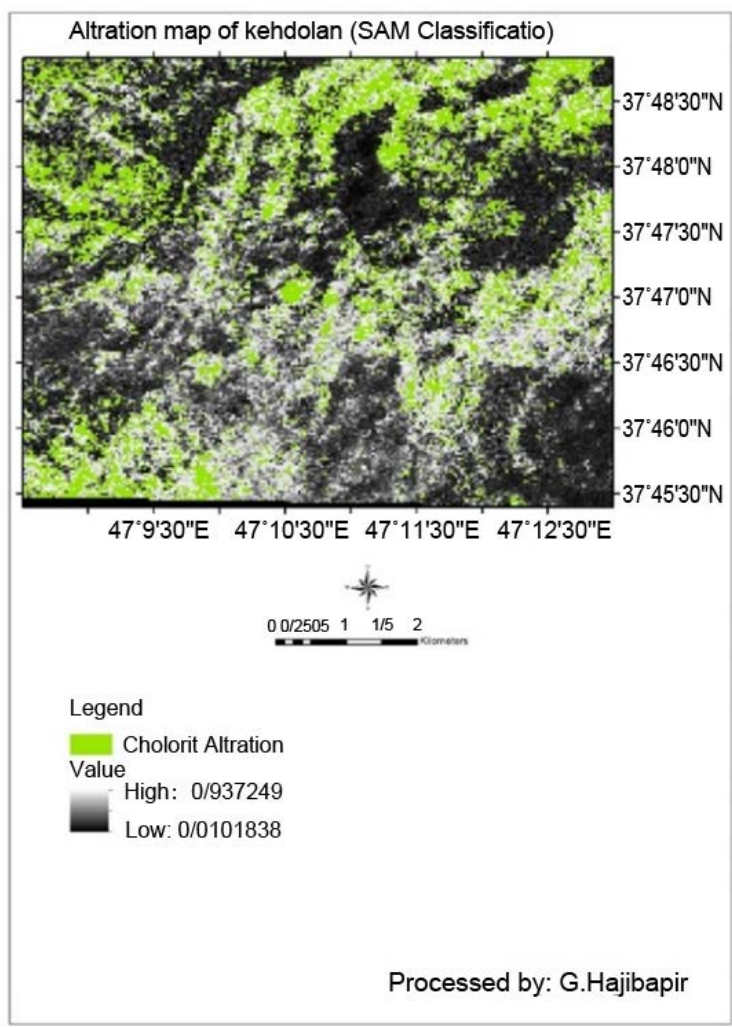

Figure 14. Cholorit map (SAM). 


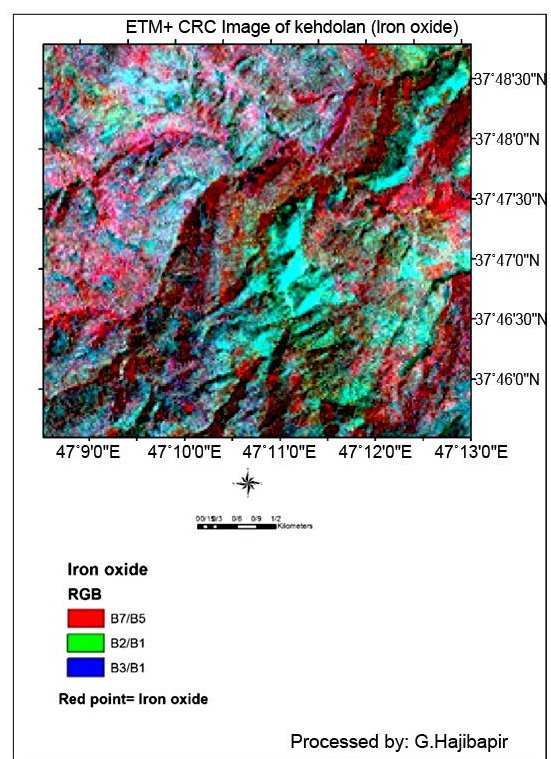

Figure 15. ETM+ iron oxide (Magnetite) image.

Table 6. ICP sample of Kehdolan area for $\mathrm{Cu}-\mathrm{Fe}$ mineral.

\begin{tabular}{|c|c|c|c|c|}
\hline Element & $X+s=$ field & $X+2 s=$ threshold & \multicolumn{2}{|c|}{$\mathrm{X}+3 \mathrm{~s}=$ probably anomaly } \\
\hline $\mathrm{Cu}$ & 2367.29 & 4640.08 & \multicolumn{2}{|c|}{6912.87} \\
\hline $\mathrm{Fe}$ & 41438.5 & 51844.5 & \multicolumn{2}{|c|}{62250.5} \\
\hline Sample name & $\mathrm{CU}(\mathrm{PPM})$ & \multicolumn{3}{|c|}{$\mathrm{Fe}(\mathrm{PPM})$} \\
\hline Kh-101 & 7699.63 & Probable anomaly & 38807 & Field \\
\hline Kh-102 & 133 & Low field & 23615 & Low field \\
\hline Kh-103 & 59 & Low field & 5516 & Low field \\
\hline Kh-106 & 5501 & Threshold & 4641 & Low field \\
\hline Kh-201 & 118 & Low field & 31320 & Field \\
\hline Kh-202 & 72 & Low field & 33415 & Field \\
\hline Kh-2-76 & 104 & Low field & 26200 & Low field \\
\hline Kh-2-78 & 7699.63 & Probable anomaly & 19500 & Low field \\
\hline Kh-2-96 & 5342 & Threshold & 32200 & Low field \\
\hline Kh-2-98 & 2247 & Field & 25800 & Low field \\
\hline Kh-2-99 & 352 & Low field & 31600 & Field \\
\hline
\end{tabular}

Table 7. XRD sample of Kehdolan area.

\begin{tabular}{cccc}
\hline Sample & Major phase & Minor phase & Trace phase \\
\hline KH-XRD-01 & Sanidine & Kaolinite & \\
& Ankerite & Gypsum & Hematite \\
& Quartz & & Ankerite \\
KH-XRD-02 & Qontmorillonite & & \\
& Quartz & \\
KH-XRD-03 & Sanidine & \\
& Hematite & \\
& Calcite & \\
& Sanidine & \\
\end{tabular}




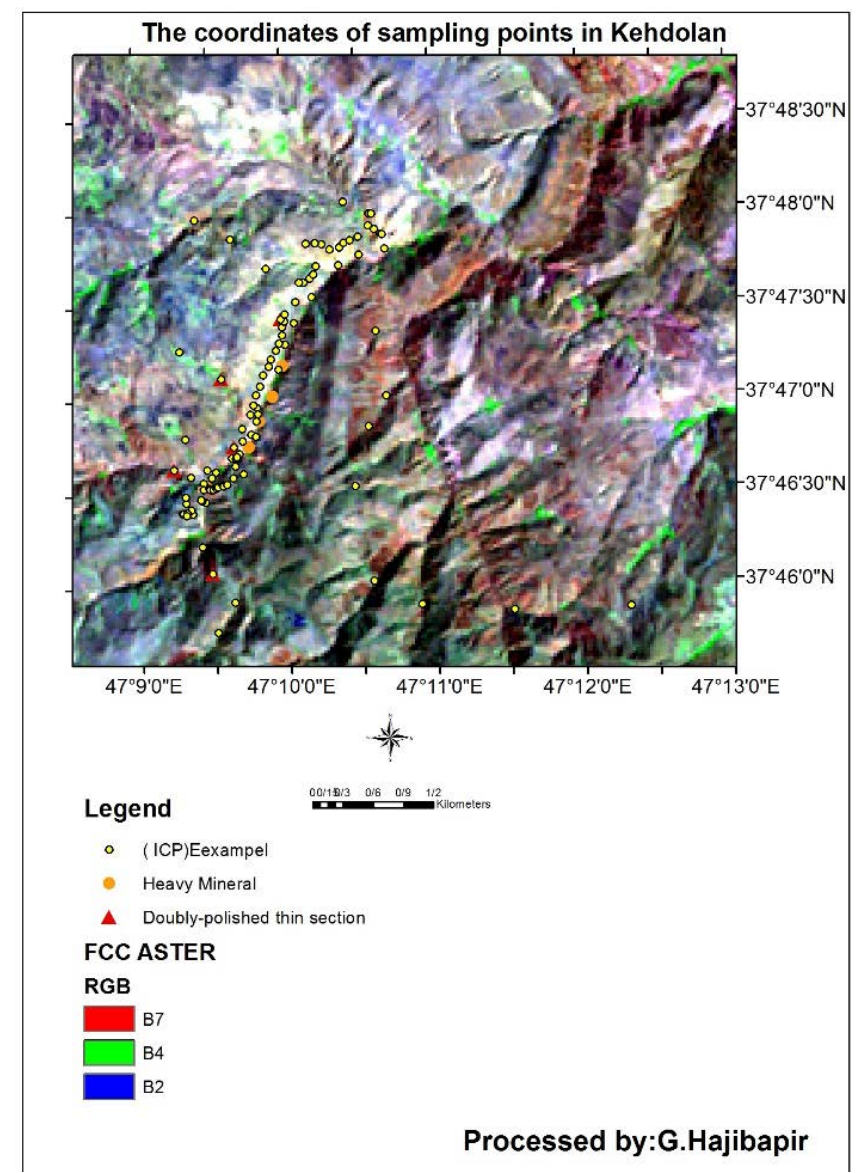

Figure 16. The coordinates of sampling points.

Table 8. Heavy mineral sample of Kehdolan area.

\begin{tabular}{cccccc}
\hline Field No. (ppm) & K-H-M-1 & K-H-M-2 & K-H-M-3 & K-H-M-4 & K-H-M-5 \\
\hline Magnetite & $1657 / 60$ & $1132 / 20$ & $1547 / 09$ & $1491 / 84$ & $3374 / 40$ \\
Hematite & $589 / 12$ & $360 / 69$ & $1104 / 60$ & $820 / 56$ & $1570 / 49$ \\
Epidotes & $588 / 00$ & $960 / 00$ & $735 / 00$ & $136 / 50$ & $870 / 83$ \\
Biotite & $3 / 36$ & $0 / 00$ & $0 / 00$ & $0 / 00$ & $0 / 00$ \\
Pyrite oxide & $28 / 00$ & $34 / 29$ & $350 / 00$ & $19 / 50$ & $148 / 81$ \\
Limonite & $196 / 00$ & $24 / 00$ & $245 / 00$ & $13 / 65$ & $174 / 17$ \\
Martite & $291 / 20$ & $35 / 66$ & $728 / 00$ & $608 / 40$ & $035 / 05$ \\
Pyrite & $20 / 00$ & $20 / 00$ & $0 / 21$ & $0 / 47$ & 0.03 \\
Chalcopyrite & $0.01(4)$ & $0.01(4)$ & $0 / 00$ & $0 / 00$ & $0.01(2)$ \\
Native copper & $0.01(1)$ & $0.01(1)$ & $0 / 00$ & $0 / 00$ & $0.01(1)$ \\
Carbonates & $10 / 84$ & $0 / 12$ & $12 / 65$ & $0 / 08$ & $24 / 52$ \\
Altered minerals & $912 / 00$ & $1144 / 29$ & $854 / 00$ & $567 / 00$ & $232 / 07$ \\
Light minerals & $0 / 00$ & $0 / 09$ & $9 / 33$ & $0 / 06$ & $18 / 10$ \\
\hline
\end{tabular}



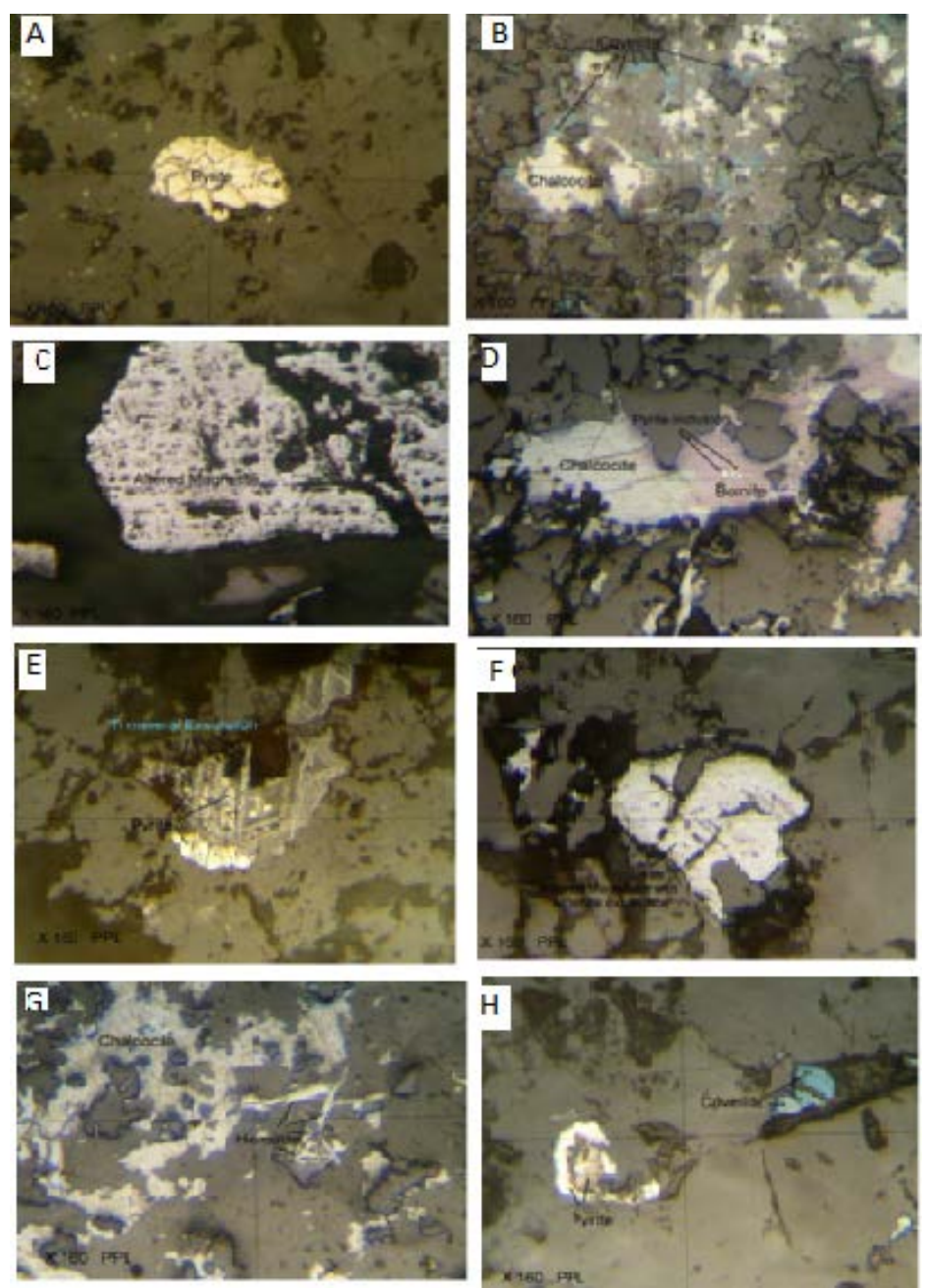

Figure 17. Doubly-polished thin section of Kehdolan area.

\section{Conclusion}

Investigation shows that ETM+ data due to its blue region spectral band can enhance the iron oxide rich areas much better than ASTER data. ASTER data due to its various spectral bands in the short wave infrared are more capable of enhancing clay bearing areas. The results showed that Crosta technique, supervised spectral angle mapping better method for enhancing alteration at ASTER data. Results obtained by study on Kehdolan area indicate the potential use of the ASTER data to fit for kind alteration of argillic, propylitic, philic, and ETM+ data are to fit for the iron oxide and relation to metal mineralization of the area. The study area Argilic alteration expands that relationship with mineralization copper which is the same direction with SW-NE faults in this area and relationship with Oligocene Syenit dyke unit as in central parts of the study. Result study for control with geological particulars, showed more probable anomaly distribution copper mineralization.

\section{Acknowledgements}

The paper was supported by Islamic Azad University, Science and research branch. The authors wish to acknowledge the research deputy of Azad University, Science and Research Branch for supporting of this study. The authors would like to thank the editors and reviewers of this paper for their comments and valuable remarks.

\section{References}

[1] Legge, C.A. (1997) Remote Sensing and Geographic Information System. Published in Association with PRAXIS 
Publishing, 137.

[2] Abrams, M. (2002) ASTER User Handbook. Jet Propulsion Lab, California, 135.

[3] Abrams, M.J., Brown, L., Lepley, R. and Sadowski, P. (1983) Remote Sensing for Porphyry Copper Deposits in Southern Arizona. Economic Geology, 78, 591-604. http://dx.doi.org/10.2113/gsecongeo.78.4.591

[4] Volesky, C.J., Stern, J.R. and Abdelsalam, G.M. (2002) Mineral Exploration Using ASTER and Landsat Data.

[5] Lillesand, T.M., Kiefer, R.W. and Chipman, J.M. (2004) Remote Sensing and Image Interpretation. 5th Edition, John Wiley \& Sons, Hoboken, 763 p.

[6] Ninomiya, Y. and Fu, B. (2005) Detecting Lithology with Advanced Space-Borne Thermal Emission and Reflectance Radiometer (ASTER) Multispectral Thermal Infrared “Radiance-at-Sensor” Data. Journal of Remote Sensing of Environment, 99, 127-139. http://dx.doi.org/10.1016/j.rse.2005.06.009

[7] Richards, J.A. (1999) Remote Sensing Digital Image Analysis. An Introduction. Springer-Verlag, Berlin, 240. http://dx.doi.org/10.1007/978-3-662-03978-6

[8] Crosta, A.P., Souza Filho, C.R., Azevedo, F. and Brodie, C. (2003) Targeting Key Alteration Minerals in Epithermal Deposits in Patagonia, Argentina, Using ASTER Imagery and Principal Component Analysis. International Journal of Remote Sensing, 24, 4233-4240. http://dx.doi.org/10.1080/0143116031000152291

[9] Sabins, F.F. (1999) Remote Sensing for Mineral Exploration. Ore Geology Reviews, 14, 157-183. http://dx.doi.org/10.1016/S0169-1368(99)00007-4

[10] Vincent, R.K. (1997) Fundamentals of Geological and Environmental Remote Sensing. Prentice Hall, Upper Saddle River, 370 p.

[11] Pearson, K. (1901) On Lines and Planes of Closest Fit to Systems of Points in Space. Philosophical Magazine, 2, 559572. http://dx.doi.org/10.1080/14786440109462720

[12] Ranjbar, H., Honarmand, M. and Moezifar, Z. (2004) Application of the Crosta Technique for Porphyry Copper Alteration Mapping, Using ETM Data in the Southern Part of the Iranian Volcanic Sedimentary Belt. Journal of Asian Earth Sciences, 24, 237-243. http://dx.doi.org/10.1016/j.jseaes.2003.11.001

[13] Honarmand, M., Ranjbar, H. and Shahabpour, J. (2012) Application of Principal Component Analysis and Spectral Angle Mapper in the Mapping of Hydrothermal Alteration in the Jebal-Barez Area, Southeastern Iran. Resource Geology, 62, 119-139. http://dx.doi.org/10.1111/j.1751-3928.2012.00184.x

[14] Jolliffe, I.T. (2002) Principal Component Analysis, Series: Springer Series in Statistics. 2nd Edition, Springer, New York.

[15] Sabins, F.F. (1997) Remote Sensing for Mineral Exploration. 3rd Edition, Freeman and Company, New York, 494 p.

[16] Thompson, A.J.B., Phoebe, L.H. and Audrey, J.R. (1999) Alteration Mapping in Exploration: Application of ShortWave Infrared (SWIR) Spectroscopy. Society of Economic Geologists' Newsletter, 39, 1-27.

[17] Mather, P.M. (2001) Computer Processing of Remotely-Sensed Images. An Introduction. 2nd Edition, John Wiley \& Sons, Hoboken, 32.

[18] Rowan, L.C. and Mars, J. (2003) Lithologic Mapping in the Mountain Pass, California Area Using Advanced Spaceborne Thermal Emission and Reflection Radiometer (ASTER) Data. Remote Sensing of Environment, 84, 350-366. http://dx.doi.org/10.1016/S0034-4257(02)00127-X

[19] Patra, S.K., Shekher, M., Solanki, S.S., Ramachandran, R. and Krishnsn, R. (2006) A Technique for Generating Natural Colour Images from False Colour Composite Images. International Journal of Remote Sensing, 27, 2977-2989.

[20] Davis, J.C. (1986) Statistics and Data Analysis in Geology. John Wiley and Sons, Hoboken, 646 p.

[21] Gupta, R.P. (2003) Remote Sensing Geology. 3rd Edition, Springer-Verlag, Berlin, 655. http://dx.doi.org/10.1007/978-3-662-05283-9

[22] Crosta, A.P. and Moore, J.M. (1989) Enhancement of Landsat Themetic Mapper Imagery for Residual Soil Mapping in SW Minas Gerais State, Brazil: A Prospecting Case History in Greenstone Belt Terrain. Proceedings of the 7th Thematic Conference on Remote Sensing for Exploration Geology, Calgary, 2-6 October 1989, 1173-1187.

[23] Jensen, J. (2000) Remote Sensing of the Environment, an Earth Resource Perspective. Prentice Hall, Englewood Cliff, $544 \mathrm{p}$.

[24] Palomera, R.P.A. (2002) Application of Remote Sensing and Geographic Information System for Mineral Predictive Mapping, Deseado, Southern Argentin. M.Sc. Thesis, ITC, Holland.

[25] Dr. Konter and Dr. Hurtado (2008) Spectral Mapping Methods: Indices and Supervised Classification. Geophysics 5336: Digital Image Processing Lab 7.

[26] Ranjbar, H., Shahriari, H. and honarmand, M. (2003) Comparison of Aster and ETM+ Data for Exploration of Porphyry Copper Mineralization: A Case Study of Sar Cheshmeh Areas, Kerman, Iran. Map Asia, 28. 
[27] Rojas, A.S. (2003) Predictive Mapping of Massive Sulphide Potential in the Western Part of the Escomb Terrian, Cuba. M.Sc. Thesis, ITC, Holland.

[28] Azizi, H., Rsaouli, A.A. and Babaei, K. (2007) Using SWIR Bands from Aster for Discrimination of Hydrothermal Altered Minerals in the Northwest of Iran (SE-Sanandaj City), a Key for Exploration of Copper and Gold Mineralization. Research Journal of Applied Sciences, 6, 763-768.

[29] Tangestani, M.H. and Moore, F. (2002) Porphyry Copper Alteration Mapping at the Meiduk Area, Iran. International Journal of Remote Sensing, 23, 4815-4825.

[30] Yetkin, E. (2003) Altration Mapping by Remote Sensing: Application to Hasandag-Mineraliz Volcanic Complex. M.Sc. Thesis, The Middle East Technical University, Turkey.

[31] Carranza, E.J.M. (2002) Geologically-Constrained Mineral Potential Mapping (Examples from the Philippines). Ph.D. Thesis, Technical University Delft, Holland.

[32] Di Tommaso, I. and Rubinstein, N. (2007) Hydrothermal Alteration Mapping Using ASTER Data in the Infiernillo Porphyry Deposit, Argentina. Ore Geology Reviews, 32, 275-290. http://dx.doi.org/10.1016/j.oregeorev.2006.05.004

[33] Lillesand, T. and Keifer, R. (2000) Remote Sensing and Image Interpretation. 4th Edition, John Wiley \& Sons, New York, 12-14.

[34] Patricia, S., Crosta, A. and De Souza, C.A. (2003) Remote Sensing Signature of the Morro Do Ouro Gold Deposit, Minas Gerais, Brazil, Using Reflectance Spectrometry: Application to Mineral Exploration Using Spaceborne Multispectral Sensors. Revista Brasileira de Geociencias, 33, 221-227.

[35] Kruse, F.A., Lefkoff, A.B., Boardman, J.B., Heidebrecht, K.B., Shapiro, A.T., Barloon, P.J. and Goetz, A.F.H. (1993) The Spectral Image Processing System (SIPS) - Interactive Visualization and Analysis of Imaging Spectrometer Data. Remote Sensing of Environment, 44, 145-163.

[36] Van der Meer, F. and De Jong, S. (2003) Imaging Spectrometery. Basic Principles and Prospective Applications. Kluwer Achademic Publishers, Dordrecht, 35.

[37] Lillesand, T.M. and Keifer, R.W. (2000) Remote Sensing and Image Interpretation. 4th Edition, John Wiley \& Sons, New York, 724 p.

[38] Kalinowski, A. and Oliver, S. (2004) Aster Minerslindex Processing, Manual. Remote Sensing Application Geosciense, 36.

[39] Ranjbar, H., Roonwel, G.S. and Ravidran, K.V. (2001) Digital Image Processing for Lithological and Alteration Mapping, Using Spot Multispectral Data, a case Study of Pariz Area, Kerman Province, Iran. Scientific Quaternary Journal, 31.

[40] Clark, R.N., Swayze, G.A., Gallagher, A., King, T.V.V. and Calvin, W.N. (1993) The U.S. Geological Survey, Digital Spectral Library: Version 1:02 to $3 \mu \mathrm{m}$. United States Geological Survey, Open File Report 93-592, 1326 p.

[41] Vincent, P.K. (1997) Fundamental of Geological and Environmental Remote Sensing. Prentice Hall, 370 p.

[42] Fujisada, H., Iwasaki, A. and Hara, S. (2001) ASTER Stereo System Performance. Proceedings of SPIE, The International Society for Optical Engineering 4540, Toulous, 39-49.

[43] Rowan, L.C., Schmidt, R.G. and Mars, J.C. (2006) Distribution of Hydrothermally Altered Rocks in the Reko Diq, Pakistan Mineralized Area Based on Spectral Analysis of ASTER Data. Remote Sensing of Environment, 104, 74-87. http://dx.doi.org/10.1016/j.rse.2006.05.014 
Scientific Research Publishing (SCIRP) is one of the largest Open Access journal publishers. It is currently publishing more than 200 open access, online, peer-reviewed journals covering a wide range of academic disciplines. SCIRP serves the worldwide academic communities and contributes to the progress and application of science with its publication.

Other selected journals from SCIRP are listed as below. Submit your manuscript to us via either submit@scirp.org or Online Submission Portal.
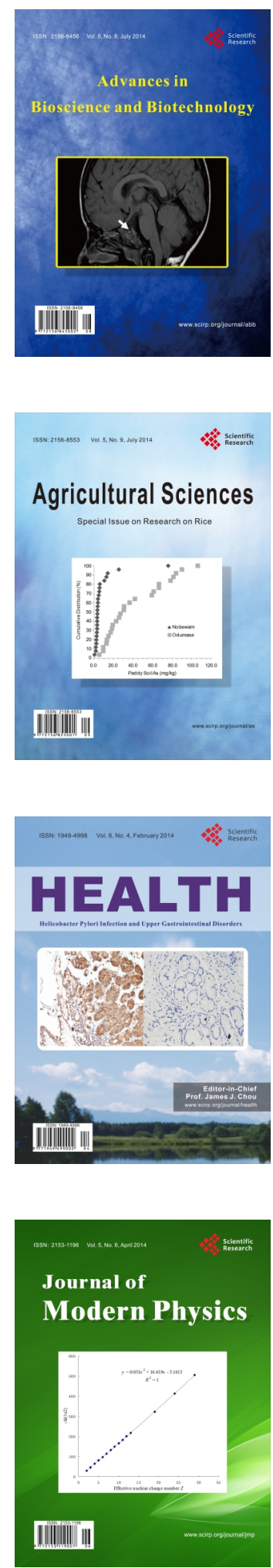
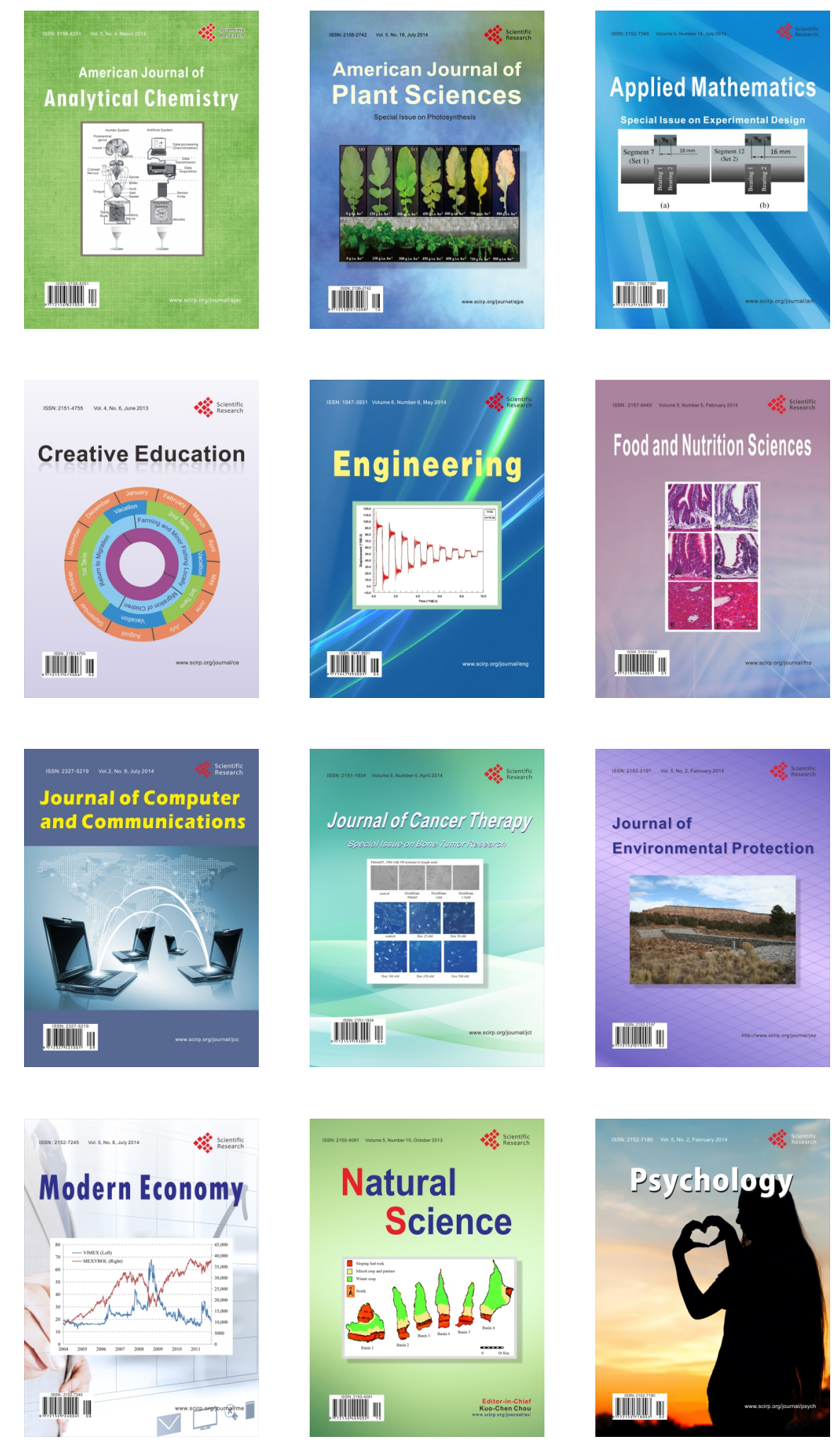